\title{
USE OF PROJECT MANAGEMENT MATURITY MODELS AS A EVALUATION FRAMEWORK FOR PROJECT RISK MATURITY ASSESSMENT
}

\author{
Adam Faifr
}

\begin{abstract}
Management of project risks has a significant impact on the success of the entire project. The importance of project risk management also means the need for continuous measurement and development of this area. Considering the existence of few specialized maturity models for this area, the aim of this paper is to analyse the extent to which it is possible to use commonly used project management maturity models (PMMMs) as a full-fledged tool for the evaluation of project risk management maturity. Based on the literature review and selected methodology, the four most frequently used models of maturity (CMMI-DEV, OPM3, PMMM, KPMMM) are analysed in more detail. Despite the predominantly exploratory nature of this paper, based on four defined criteria, three of the above PMMMs can also be used as models for evaluating and improving Project Risk Management. While one of the outputs of this paper is the creation of an evaluation scale for the PRM assessment, based on the regularities of the models used. By outlining the possibility of using already existing PMMMs, the results of this paper contribute to the evolving field of improving the management of project risks as a key project management area. In addition, results point out the expanded use of already existing PMMMs.
\end{abstract}

Keywords: project risk management, maturity model, project management evaluation, risk management maturity, PRM, CMMI, OPM3

\section{INTRODUCTION}

An integral part of project management is management of project risks. Namely, the degree of uncertainty in the project management environment is analogously linked to the potential existence of risks. Thus, project risk management is a core discipline in most industries and can be defined as a process that dynamically minimizes the level of risk by identifying and evaluating potential risk events, developing a response plan, and actively monitoring risks during project implementation. (Irizar and Wynn, 2018)

In contrast, Nicholas \& Steyn (2017) claim that project management itself is a method of minimizing the risk associated with uncertain behaviour. One way or another these two areas are closely interlinked and thus the ability to manage project risks has a key impact on the future success of the project, which is also confirmed by some authors, while the quality of the risk management process in projects is then derived primarily from the maturity of the organization in this field. (Crispim et al., 2018, de Carvalho \& Rabechini Junior, 2014)

So-called maturity models are used as tools for systematic improvement and measurement of the levels of individual business areas. Due to the different views on the very concept of maturity, there is a number of models that evaluate the organization in different ways. Based on literature reviews there is up to 60 model for assessing project management maturity. (Iqbal, 2013)

Despite the close link between successful risk management and project success, very few contributions and models were developed specifically address this area. In the area of project risk management maturity (hereinafter as PRMM), four models have been developed in last 
decade. (Hopkinson, 2012; Hartono et al., 2014; Irizar \& Wynn, 2018; Chapman, 2019). However, their widespread acceptance is hindered by their applicability only in some of the industrial areas, such as the construction industry (Hartono et al., 2014), automotive (Irizar \& Wynn, 2018) or areas that do not involve creating permanent physical assets on the ground. (Chapman, 2019)

Previously identified barriers of the use of project maturity models, such as small size of company, cost difficulties and time-consuming assessment (Staples et al., 2017), are thus emphasized in the case of improvement of only one of the key project areas.

One of the ways to overcome the shortcomings resulting from the models tailored for selected industry or from assessment specified only on specific project area, is to use general models for project management maturity. However, this procedure is conditioned by the assumed possibility to evaluate only partial project areas within the assessment.

In line with this statement, the aim of this work is to examine the extent to which existing general maturity models can be used to improve and evaluate PRMM, which would provide both insight into project management as a whole and its individual areas, and including risk management. The procedure used (creation of a new model based on the principles and knowledge of the previously created model) also fully respects the principles that are commonly applied in the field of maturity model's development. (Backlund et al., 2014)

Given that many of the models used are based on the PMBOK methodology (2004), which considers risk management as one of the knowledge areas of project management, it is assumed that this procedure will be applicable. Given that each maturity model should also provide a basis for further improvement, then such evaluation should allow the area of project risks to be further improved. (Crawford, 2014)

\section{THEORETICAL REVIEW}

With regards to the objectives of this work, the theoretical background is defined in this part. On this basis, some sub-models will be analysed later. The following section summarizes the research on the topic of project management maturity and use of project maturity models.

\section{Project management development within organizations}

The development and improvement of project management in organizations is associated with the new millennium and businesses processes maturity efforts. (Cooke-Davies \& Arzymanow, 2003, Mullaly, 2006) When searching for a definition of the term "maturity", at least two possible definition are available. For example, Crawford (2014) or Nicholas \& Steyn (2017) consider an organization's maturity as an organization's ability to achieve consistent results, while Gartner (2012) deduces project management maturity as an organization's ability to embrace such things as project management or portfolio management, and at what level of complexity and effort. Based on analysis performed in recent years (Backlund et al., 2014, Görög, 2016), the organization's maturity in project management is then determined by two main factors: (a) Appropriate and efficient use of project management toolkit and knowledge; (b) Appropriate placement of project management into the organizational strategic context.

As concluded, for example, by Clealand \& Bidanda (2015), projects do not take place in isolation and self-servingly, but always have a linkage to the strategic goals. For example (Cooke-Davies et al., 2009, Project management institute, 2013)

Research conducted since the anchoring of the term "maturity" derive a number of both internal and external benefits associated with increasing maturity in organizations, such as increased 
quality of outputs (Crawford, 2014, Mikosik, 2014), optimizing the organization's risk management, improving the organization's human resources management motivating organizational culture. (Klein et al., 2015, Miklosik, 2014, Selleri Silva et al., 2015), the establishment of project standards in the organization (Irfan et al., 2019), a proactive and systematic approach to problem solving (Bharathi et al., 2012), increased reputation of the organization in the market (Miklosik, 2014, Nicholas \& Steyn, 2017) or gradual expansion of competitive advantages. (Miklosik, 2014, Nicholas \& Steyn, 2017).

In summary, high maturity of project management refers to positive effect on performance (Albrecht \& Spang, 2014, Irfan, 2019, Klein et al., 2015, Mullaly, 2006) However, based on some other research, there is a paradigm shift in this regard, where for example Yazici (2009) finds that project performance is also determined by organization culture to a great extent. Brooks et al. (2014) generally mention insufficient empirical evidence of the linkage between performance and maturity.

Part of the research has just been devoted to the role of complexity to the need to increase the maturity of the organization and the corresponding higher performance of the organization. However, the previously demonstrated amplifying effect on performance (Albrecht \& Spang, 2014, Backlund et al., 2014, Demir \& Kocabas, 2010) or on high-level of maturity in a more complex environment (Pretorius et al., 2012) is partially negated by recent research (Ogonowski \& Madziński, 2019) of the largest Polish logistics organizations, which points to the low maturity of these organizations and to the unsystematic approach to project management.

The context of the organization then has its role in the maturing process as well. Pasian \& Williams (2014) mention the role of non-process factors here, especially in case of "human factors". For example, in the case of involving senior management in the whole process (Crawford, 2014; Nicholas \& Steyn, 2017), which is also related to the above-mentioned determinants of maturity.

Although improving project management through maturity models can be mistaken for panacea (Crawford, 2006), it can be concluded that the success of sub-projects is determined by significantly more factors. Long-term effort is then associated with investment and related pressure on efficiency. Thus, it is always necessary to consider the future profitability of the whole effort. (Project management institute, 2013) Each organization achieves its effectiveness at a different level of maturity.

\section{Use of Project Management Maturity Models}

As Clealand \& Bidanda (2015) mention, so-called maturity models have been developed with the need to look beyond the level of sub-project management and to map the current project management system in the organization. More precisely, maturity models are considered as a tool that can be used to measure and evaluate individual partial aspects of project management of the organization. (Nicholas \& Steyn, 2017)

However, the applicability of the models does not end with the measurement itself. Determining the level, on the one hand, allows the organization to know its position and its shortcomings, and, by analogously the results point to the possibilities for further improvement and its form. As Crawford (2014) adds: "By compiling its own evaluation, the company shows, among other things, the will to improve its processes."

According to Iqbal (2013), there are already more than 60 different models and their variants as there was about 30 such models identified ten years earlier (Grant \& Pennypacker, 2006). This fact is given by very nature of maturity assessment, where there is no type of model or 
specific model that is universally applicable and useful for any kind of organization. (Backlund et al., 2014) This is based, among other things, on the different ideas and needs of organizations regarding the improvement of their competencies. Thus, some models are usually used in given industry.

Along with the development of new models, the principles of how to further categorize models are also developing. Within the models of maturity, two main categories are considered: (a) Hierarchical models - maturity is characterized by the number of skills and competencies that the organization has; (b) Process models - assessment of maturity based on the areas that the company considers in project management (Tahri \& Drissi-Kaitouni, 2015).

Some authors also propose other categorization options, probably in connection with the growing number of models, for example Torres (2014) divides models according to the approach of determining the level of graduation (staged models and continuous models), Görog (2016) then expands the possibilities of categorization further by underlying notion, primary aim of assessment and type of assessment.

Part of the papers on the topic of maturity models deals with criticism, which mainly concerns the shortcomings of the models themselves or the identification of barriers to use. Due to the nature of the similarity of certain models, as there are built on the similar principles (Ferreira de Souza \& Gomes, 2015, Görög, 2016), these characteristics are common to all the models created so far. The main shortcomings of the models compiled so far are considered to be too much emphasis on explicit knowledge of the organization and underestimation of the role of tacit knowledge, (Görög, 2016, Nicholas \& Steyn, 2017) for example in the form of competencies and experience of project managers, which are not transferable but largely determine project success. This factor has already been mentioned in the previous section, in relation to the limits of maturity and performance.

Another criticism concerns the overemphasis on the procedural side of evaluation, where the condition for compiling is a procedural view of the organization (Görög, 2016), insufficient consideration of the organizational context (Irizar \& Wynn, 2018) and last but not least the difficulty of compiling the assessment. (Tahri \& Drissi-Kaitouni, 2015)

On the specific example of the CMMI model, Staples et. al (2007) deals with the topic of the difficulty of assessing the evaluation, which is also a barrier to the use of models. In this case, barriers are given primarily by the size of the organization, which "does not have enough time to implement", has "constrained budget or "the methodology is not applicable to the projects of given organization". (Staples et. al, 2017) Another barrier to long-term use identified is the fact that while in the primary stages the transition to a higher level is relatively easy, most companies never surpass the second level of maturity, either in terms of the difficulty of moving to a higher level or achieving efficiency at this point. (Crawford, 2014, Mullaly, 2006, Staples et al., 2007) Keshta (2020), in this context, then reveals that only a small number of organizations make full use of the models.

From the perspective of the analysis of partial models, only one research has so far focused on the frequency of use of partial types of models (Ferreira de Souza \& Gomes, 2015). The remaining part of the research mainly deals with the study of specific models. From this perspective, the greatest attention so far has been given to CMMI models and their counterparts. This is also confirmed by relatively frequently created standards and methodologies based on CMMI model (von Wangenheim et al., 2010, Cheng et al., 2011, Septiana Pane \& Sarno, 2015, Domínguez et al., 2018, Gonçalves et al., 2018).

In general, models of maturity are constantly evolving. One direction of development may be the replacement of shortcomings of existing models (e.g. Görör, 2016), another in tailoring the 
models to a certain industry (e.g. Čech et al., 2018) or in developing models for certain project sub-areas (e.g. the section 0$)$.

\section{Project risk management maturity models}

The development of maturity models, which would be designed specifically for PRM, was preceded by the previous identification of risk management as one of the determinants of project success. Mishra et al. (2015) examined whether a higher level of maturity measured by the CMMI model can mitigate the negative effects of project risks on project performance. Crispim et al. (2018) tried to compare the maturity of PRM to the performance of the project. Finally, de Carvalho \& Rabechini Junior (2014) examined the relationship between risk management and project success.

In all the mentioned research, the connection between PRM and project success / performance was confirmed to some extent. Although, for example, Mishra et al. (2015) concludes that in cases where low levels of project risk, increasing levels of the maturity process can adversely affect project performance. De Carvalho \& Rabechini Junior (2014) and Crispim et al. (2018) then point to the fact that PRM has an impact on the project success, but with regard to the complexity of the project. The need to create a specialized model is indirectly mentioned by Papke-Shields et al. (2010), who point out that despite the fact that elements of management are one of the competencies of project management, this area is consistently found to be immature. The positive impact of PRM maturity was last investigated last year. (Hartono et al. (2019)

In terms of modelling for PRM, there are currently four different models (Hopkinson, 2012; Hartono et al., 2014; Irizar \& Wynn, 2018; Chapman, 2019), where modelling for PRM is associated with the adaptation of risk management models to need for projects. Hopkinson's Project Risk Maturity Model (Hopkinson, 2012) is an extension of Hilson's model of assessing risk management capability against recognized standards (Irizar \& Wynn, 2018). Irizar \& Wynn (2018) is then based on Hopkinson's model, tailored directly for the needs of the automotive industry. The model from Hartono et al. (2014) is also validated, but for construction industry.

The most recently developed model is Chapman's model, which, unlike the current models, considers three critical areas affecting PRM, namely the objectives of PRM, core PRM activities and barriers to the implementation of effective PRM. (Chapman, 2019)

\section{METHODOLOGY AND RESEARCH OBJECTIVES}

Given the nature of the research question, this research is considered as qualitative exploratory research. According to Lune \& Berg (2017), such a design is approached in cases where the methodological approach is particularly appropriate for research that seeks f.e. to explore real linkages and processes in organizations. (Marshall \& Rossman, 2014) In the case of this work, it is an examination of the possibility of the application Project Management Maturity Models in organizations, as a tool for evaluation of Project risk management maturity.

Based on the above literature review, the comparative criteria will be defined and suitable models will be selected (Flick, 2014). Selected models will consequently be compared in order to sufficiently respond the research question. The detailed description of research steps is revealed in following sections.

\section{Comparative criteria}

The next step in the research is the definition of comparative criteria, which are defined based on the required characteristics of the considered PRMMM. 
Comparative criteria are defined and explained based on the literature review and are defined as follows:

The expected characteristic of the maturity model is the ability to accurately determine the level of maturity (Crawford, 2014). This assumption is also based on a staged approach of maturity improvements. (Tahri \& Drissi-Kaitouni, 2015, Torres, 2014) Thus, each of the selected models will be evaluated in terms of the assessment processing system, so as to provide comparable possibilities with the already created models of PRMMMs.

The second precondition for the suitability of the model is the fact that, based on the assessment the process (PRM) itself can be subsequently improved. (Crawford, 2014, Project Management Institute, Inc., 2013) This characteristic will be examined in selected models whether the model itself distinguishes PRM as the whole process or whether the key aspect of risk management are distinguished as well.

If the standard model is to be used to improve PRM, it must provide a "roadmap" for improvement according to the required characteristics. (Crawford, 2014, Demir \& Kocabas, 2010) Criterion analyses the extent of how the PRM maturity can evaluated regardless the overall project management maturity.

As mentioned in the literature review (Hartono et al., 2019), the term maturity is not clearly defined. Being inspired by Görög's classification (2016), this comparative criterion compares the way the maturity is increased within a given model.

\section{Selection of suitable models}

As the comparative criteria were defined, the selection of suitable models follows. Respecting the common methodology (Flick, 2014), the sampling is oriented on formal and substantial criteria. Criteria of selection has to be driven by the representativeness of a sample for the population. (Flick, 2014) In case of this research, the analysis was limited to the four most frequently mentioned models, based on research from 2015. (Ferreira de Souza \& Gomes, 2015). This procedure is also chosen on the assumption that the existing models are similar in their functionality and principles of evaluation. (Ferreira de Souza \& Gomes, 2015, Görög, 2016) In accordance to this statement, in the end the research is supposed to make statements that can applied not just for selected samples but can be widely applied. (Lune \& Berg, 2017)

Consequently, the following models of maturity will be further evaluated: (a) Capability Maturity Model Integrated (abbreviated as CMMI); (b) Organizational Project Maturity Model (OPM3); (c) Project Management Maturity Model (PMMM); (d) Kerzner's Project Management Maturity Model (KPMMM).

In accordance with the exploratory nature of the research questions of this paper, the partial models will first be described and analysed in detail so that the models can be evaluated in individual aspects.

\section{ANALYSIS OF SELECTED MATURITY MODELS}

\section{Capability Maturity Model Integrated}

Developed by PM Solutions, the CMMI model uses the ten knowledge areas listed in the PMBOK ${ }^{\circledR}$ Guide (2004) and is developed in collaboration with industry, government and academia. (Crawford, 2014; Ferreira de Souza \& Gomes, 2015) In contrast to the originally developed CMM model, it can be used in other industries than just software and IT development. Even so, it is used mainly by organizations in this industrial area. (Crawford, 2014) 


\section{Evaluation methodology and scale}

The CMMI defines two different approaches to improvement (Selleri Silva et al., 2015). While the first approach allows organizations to improve processes gradually, in individual areas, the second approach allows for improvements based on the improvement of sets of related areas. There are two different scales and two different perspectives for improvement for these needs: (a) Capability level; and (b) Maturity level.

Capability is assessed separately for each of the organization's 22 defined processes, on 4-point scales. On the other hand, maturity is defined in five levels and depends on the number of controlled processes of the organization and their maturity, in five levels. (Chrissis et al., 2011)

Based on the methodology of the model, it follows that the organization can achieve the required maturity only if all the defined processes for this level and all lower levels are sufficiently mature. Although the maturity model itself defines the required areas (processes), it no longer specifies the specific steps to be taken to achieve a given level of maturity. (Chrissis et al. 2011; Keshta, 2020)

\section{Risk management within the model of CMMI-DEV}

Within this model, risk management is one of 22 defined processes, and is assigned to the area of project management processes falling within the framework of the organization's 3 degree of level of development. At the same time, a link to other defined processes in this level is determined, namely within the process of Project Management Integration (IPM) and Quantitative Project Management (QPM). The defined goal of this process is: "Identification of potential problems before they occur, so that individual steps can be planned and implemented as needed throughout the project" (Chrissis et al., 2011)

The specific objectives of this process include preparatory risk management activities, risk identification and analysis, and risk mitigation. The first step is the activity of defining a risk management strategy, which usually takes the form of an established risk management plan. The second step is to define how to identify and analyse risks. The last area is the definition of steps defining the possibilities of risk treatment and their monitoring in case tolerable limits for risk acceptance are exceeded (Chrissis et al., 2011)

In accordance with the methodology for measuring maturity, this process can be characterized at individual levels even in the case of risk management. Due to the interweaving of a tiered and gradual approach, a total of 6 possible combinations of process maturity and the level of maturity of the organization are defined. The levels are defined in Tab. 1.

Tab. 1 - Project risk management maturity model (CMMI). Source: based on Williams (2006)

$\begin{array}{ll}\begin{array}{l}\text { Capability level } \\ 0 \text { - Incomplete }\end{array} & \begin{array}{l}\text { Maturity level } \\ 1 \text { - Initial }\end{array} \\ \begin{array}{l}\text { 1-Performed } \\ \text { (3- Managed }\end{array} & \text { 2- Managed } \\ & \\ 3 \text {-Defined }) & 3-\text { Defined } \\ & \begin{array}{l}4-\text { Quantitatively } \\ \text { managed }\end{array} \\ & 5 \text { - Optimizing }\end{array}$

Description

Risk management is either not implemented or is only partially implemented. One or more specific risk management objectives are not met.

The organization's risk management procedures satisfy all the specific objectives. Risk management is planned and implemented in accordance with the principles of the organization, employs qualified people who have sufficient resources to produce controlled outputs, includes relevant stakeholders; is monitored, controlled and controlled; and is evaluated for adherence to the process description.

Risks are managed on the same principle as in the previous level. However, the process is already modified according to the process standards of the organization. In contrast, the risks are managed by statistical and other quantitative techniques. Quantified process goals are set. The quality and performance of the process is understood on the basis of quantifiable data.

Quantitative management process adapted to be able to meet both current and anticipated business goals. The process is constantly optimized. Deviations in process outputs are minimized. 
The above table shows that in the perspective of the CMMI model, the specific form of the risk management process is determined both by the capability but also by the maturity of the entire organization. In this case, risk management is determined by the ability of the process to meet all specific process objectives and by process management principles within the organization. (Williams, 2006)

\section{Organizational Project management maturity model (OPM3)}

OPM3 was developed to provide organizations the way how to understand project management and measure maturity despite a comprehensive and broad set of best practices in project management (Ferreira de Souza \& Gomes, 2015)

Project Management Institute, Inc. (2013) then describes the model as follows: "OPM3 is the integration of people, knowledge and processes that are supported by tools across all domains based on a value strategy for a given target market." (Project Management Institute, Inc., 2013)

\section{Evaluation methodology and scale}

Maturity is assessed in the model by comparing the current state of the organization with predefined "best practices", of which the model considers approximately 600. (Matassa, 2006) Maturity itself is then defined based on whether and, if so, to what extent the "best practices" are applied in organization. At the same time, each of the practices is assigned to a certain level of continuous improvement, which is defined by a total of four.

The maturity assessment itself, as with other maturity models (such as PMMM), outlines a possible way forward for improvement, in the context of defined best practices. The basis for improvement and thus increasing maturity is the so-called "improvement planning directory", which lists all the best practices, a description of their optimal state, a list of competencies necessary to fulfil them and their connection with other practices. Based on this basis, the organization can prioritize partial steps, either regarding to the expansion of competencies, or by expanding the applied practices. (Project Management Institute, Inc., 2013)

\section{Risk management within the OPM3}

The link to project risk management can be found in this model in the knowledge base, which defines individual best practices based on the PMBOK Guide (2004). Specifically, these are 6 partial processes of standard project risk management. All of these processes are defined in the following Tab. 2, where the processes within the individual phases of improvement are also described.

Tab. 2 - Project risk management maturity model (OPM3). Source: own processing based on PMI, Inc. (2013)

\begin{tabular}{|c|c|c|c|c|}
\hline Process / Improvement phase & Standardize & Measure & Control & Improve \\
\hline Plan Risk Management & \multirow{6}{*}{$\begin{array}{l}\text { Standards are } \\
\text { established }\end{array}$} & \multirow{6}{*}{$\begin{array}{l}\text { Measures are } \\
\text { established, } \\
\text { assembled, } \\
\text { and analysed. }\end{array}$} & \multirow{6}{*}{$\begin{array}{l}\text { Controls are } \\
\text { established and } \\
\text { executed to } \\
\text { control the } \\
\text { stability of the } \\
\text { process. }\end{array}$} & \multirow{6}{*}{$\begin{array}{l}\text { Process problem areas are assessed, } \\
\text { root causes are identified, process } \\
\text { improvement recommendations are } \\
\text { collected, and process improvements } \\
\text { are implemented. }\end{array}$} \\
\hline Identify Risks & & & & \\
\hline Qualitative risk analysis & & & & \\
\hline Quantitative risk analysis & & & & \\
\hline Plan Risk Responses & & & & \\
\hline Project control risks & & & & \\
\hline
\end{tabular}

The PRMM level fully corresponds to the principles of evaluating the PMM, while the maturity of each sub-process can be defined. (Project management Institute Inc., 2013) A closer analysis of the "improvement planning directory" could also compile a functional model of project risk management maturity, which would consider both individual and related processes, necessary competencies and other related best practices. 


\section{Project management maturity model}

The Project Management Maturity Model (PMMM) is a formal tool developed by PM Solutions that seeks to measure maturity in an organization's project management. The goal of the PMMM methodology, according to author (Crawford, 2014), is to enable any organization to develop project management skills systematically and effectively. (Ferreira de Souza \& Gomes, 2015)

\section{Evaluation methodology and scale}

The evaluation principle is based on the above CMM model and works with 10 knowledge areas of project management defined in the PMBOK® Guide (2004). The model has five different levels of maturity.

Each of the defined 10 knowledge areas is further divided into several knowledge sub-areas within the evaluation, while the maturity of each of them is evaluated. This assessment is determined based on a predefined description for the sub-area. The maturity of each of the areas is given by the lowest level within the given knowledge area. The maturity of project management in an organization is then determined on the same principle based on the maturity of each of the 10 knowledge areas. (Crawford, 2014)

The evaluation of an organization's maturity is therefore derived from the least developed subregion across the organization. Thus, a gradual improvement in the maturity of the organization occurs by eliminating weaknesses in the competencies of the organization.

\section{Risk management within the PMMM}

Within the PMBOK (2004), risk management is defined among 10 knowledge areas of project management. Due to the evaluation system within this model, the area of risk management is also evaluated individually.

Based on the theoretical definition, as within the OMP3 model, risk management is divided into six key components, while the risk management documentation system is also considered. The table below defines the individual levels of maturity within the PMMM model.

Tab. 3 - Project risk management maturity model (PMMM). Source: own processing based on Crawford (2014)

\begin{tabular}{|c|c|c|c|c|c|}
\hline & Initial Process & $\begin{array}{l}\text { Structured } \\
\text { Process and } \\
\text { Standards }\end{array}$ & $\begin{array}{l}\text { Organizational } \\
\text { Standards and } \\
\text { Institutionalized } \\
\text { Process }\end{array}$ & Managed Process & Optimizing Process \\
\hline $\begin{array}{l}\text { Risk } \\
\text { management } \\
\text { Planning }\end{array}$ & $\begin{array}{l}\text { No risk } \\
\text { management } \\
\text { plan defined. }\end{array}$ & $\begin{array}{l}\text { Existing risk } \\
\text { management } \\
\text { plan mainly for } \\
\text { large projects. }\end{array}$ & $\begin{array}{l}\text { The plan is used by } \\
\text { all projects, } \\
\text { individual areas of } \\
\text { risk management are } \\
\text { specified. }\end{array}$ & $\begin{array}{l}\text { The principles of risk } \\
\text { management are adapted } \\
\text { to the needs of each } \\
\text { project. }\end{array}$ & $\begin{array}{l}\text { Value and improvement } \\
\text { are key aspects in } \\
\text { drawing up risk } \\
\text { management plans. }\end{array}$ \\
\hline $\begin{array}{l}\text { Risk } \\
\text { Identification }\end{array}$ & $\begin{array}{l}\text { Risks are not } \\
\text { identified } \\
\text { systematically. }\end{array}$ & $\begin{array}{l}\text { There is a } \\
\text { framework plan } \\
\text { for identification, } \\
\text { focusing on key } \\
\text { areas. }\end{array}$ & $\begin{array}{l}\text { Documentable and } \\
\text { repeatable process } \\
\text { of risk identification } \\
\text { in projects. }\end{array}$ & $\begin{array}{l}\text { Full integration of risks } \\
\text { into the cost plan and } \\
\text { project schedule. }\end{array}$ & $\begin{array}{l}\text { Continuous } \\
\text { improvement of the risk } \\
\text { identification process. }\end{array}$ \\
\hline $\begin{array}{l}\text { Qualitative } \\
\text { Risk Analysis }\end{array}$ & $\begin{array}{l}\text { Improvised } \\
\text { method of } \\
\text { analysis. }\end{array}$ & $\begin{array}{l}\text { Standard } \\
\text { methodology, } \\
\text { usually a three- } \\
\text { step approach. }\end{array}$ & $\begin{array}{l}\text { Methods of analysis } \\
\text { are more } \\
\text { sophisticated. }\end{array}$ & $\begin{array}{l}\text { Advanced methods are } \\
\text { used to estimate the } \\
\text { impact on most aspects } \\
\text { of the project. }\end{array}$ & $\begin{array}{l}\text { Analysis based on } \\
\text { previous experience, } \\
\text { continuous improvement } \\
\text { of analysis methods. }\end{array}$ \\
\hline $\begin{array}{l}\text { Quantitative } \\
\text { Risk Analysis }\end{array}$ & $\begin{array}{l}\text { Improvised } \\
\text { method of } \\
\text { analysis. }\end{array}$ & $\begin{array}{l}\text { Standard } \\
\text { methodology, } \\
\text { semiquantitative } \\
\text { approach. }\end{array}$ & $\begin{array}{l}\text { Advanced } \\
\text { quantitative } \\
\text { methods. }\end{array}$ & $\begin{array}{l}\text { Advanced methods are } \\
\text { used to estimate the } \\
\text { impact on most aspects } \\
\text { of the project. Measuring } \\
\text { the effectiveness of } \\
\text { measures. }\end{array}$ & $\begin{array}{l}\text { Analysis based on } \\
\text { previous experience, } \\
\text { continuous improvement } \\
\text { of analysis methods. }\end{array}$ \\
\hline $\begin{array}{l}\text { Risk Response } \\
\text { Planning }\end{array}$ & $\begin{array}{l}\text { Reactive } \\
\text { approach. }\end{array}$ & $\begin{array}{l}\text { Basic } \\
\text { methodology, } \\
\text { basic integration } \\
\text { with the project } \\
\text { plan. }\end{array}$ & $\begin{array}{l}\text { Standardized } \\
\text { measures. All risks } \\
\text { of the project are } \\
\text { addressed. }\end{array}$ & $\begin{array}{l}\text { Full integration with cost } \\
\text { plans, schedule and other } \\
\text { project areas. }\end{array}$ & $\begin{array}{l}\text { Retrospective evaluation } \\
\text { of the effectiveness of } \\
\text { the measure, even on the } \\
\text { basis of drawing on the } \\
\text { project reserves. }\end{array}$ \\
\hline
\end{tabular}




\begin{tabular}{|c|c|c|c|c|c|}
\hline Risk Control & $\begin{array}{l}\text { Response only } \\
\text { if risk occurs. }\end{array}$ & $\begin{array}{l}\text { Each project } \\
\text { team has its own } \\
\text { approach to risk } \\
\text { control. }\end{array}$ & $\begin{array}{l}\text { All projects } \\
\text { continuously } \\
\text { monitor risks, } \\
\text { ongoing adjustments } \\
\text { in measures. }\end{array}$ & $\begin{array}{l}\text { Controlling system fully } \\
\text { integrated with the } \\
\text { corporate system. }\end{array}$ & $\begin{array}{l}\text { A documented process } \\
\text { using risk assessment } \\
\text { and data on the current } \\
\text { state of risk management } \\
\text { helps in management } \\
\text { decisions during project } \\
\text { implementation. }\end{array}$ \\
\hline $\begin{array}{l}\text { Risk } \\
\text { Documentation }\end{array}$ & $\begin{array}{l}\text { Risks are not } \\
\text { documented. }\end{array}$ & $\begin{array}{l}\text { Historical data, } \\
\text { inconsistent } \\
\text { collection are } \\
\text { considered. }\end{array}$ & $\begin{array}{l}\text { Historical data, } \\
\text { triggers of negative } \\
\text { events, treasure for } \\
\text { other projects are } \\
\text { collected. }\end{array}$ & $\begin{array}{l}\text { Project documentation is } \\
\text { fully organizational. }\end{array}$ & $\begin{array}{l}\text { Experiences from } \\
\text { previous projects are } \\
\text { captured and used to } \\
\text { improve data collection. } \\
\text { Evaluations are carried } \\
\text { out after the end of the } \\
\text { project. }\end{array}$ \\
\hline
\end{tabular}

\section{Kerzner's Project Management Maturity Model}

This model of maturity (KPMMM) is presented by its author as an extension of the CMMI model focused on project management. (Ferreira de Souza \& Gomes, 2015) The resulting maturity of the organization is determined by the degree of integration of these elements within the organization. (Kerzner, 2001)

\section{Evaluation methodology and scale}

The model is based on a tiered approach to assessing the maturity of the organization, distinguishing a total of 5 different levels. The model proposed by Harold Kerzner differs from the others by a different methodology for evaluating each level of maturity, with each level not evaluating the development of sub-processes or competencies, but monitoring individual aspects to match the profile of the organization at that level.

Unlike other used maturity models, Kerzner also considers the possibility of interweaving individual levels, where improvement does not always take place sequentially. As mentioned above, in addition to project management, this model, for example, works with TQM methods and the like. (Kerzner, 2001; Ferreira de Souza \& Gomes, 2015)

Another difference compared to other (previously described) models is the fact that not every increase in the level of maturity of an organization is associated with increasing maturity and integration of specific processes. This is the first and fourth stages of maturity. Thus, none of these phases is associated with changes in normal business processes. (Kerzner, 2001)

\section{Risk management within KPMMM}

Due to the different approach to the evaluation of each of the levels of maturity, in the case of this model, the evaluation of the maturity of the project risk management in the organization cannot be extrapolated from the partial results. It should be added, however, that the model works with a general methodology for risk management, and the level of development of the entire project management in the organization therefore depends on its level by analogy. However, the model introduced in 2001 does not fully reflect the current risk management methodology.

\section{SUMMARY AND DISCUSSION}

In the previous section 4 , the 4 most frequently used models of project management maturity were described and analysed in detail, in order to summarize the principles of how the evaluation takes place in the model and how the topic of project risk management is anchored in this model.

In Tab. 4, selected models are compared based on previously defined criteria. It is a qualitative evaluation of each aspect of the model regarding to use for project risk maturity assessment and improvement. From the point of view of comparative criteria, neither of the models is similar 
to the other in more than two criteria. In Tab. 4, selected models are compared based on previously defined criteria. It is a qualitative evaluation of each aspect of the model regarding to use for project risk maturity assessment and improvement. From the point of view of comparative criteria, neither of the models is similar to the other in more than two criteria.

As the result shows, three of the four analysed models can be used as PRM maturity models. There is only exception in example of KPMMM, which, although based on the methodology of the CMMI model (Ferreira de Souza \& Gomes, 2015), is unsuitable for further evaluation. Therefore, this model is excluded from further discussion.

Tab. 4 - Comparison of project risk maturity models. Source: own research

\begin{tabular}{|c|c|c|c|c|}
\hline & $\begin{array}{l}\text { Definition of } \\
\text { PRMM levels }\end{array}$ & Evaluation perspective & $\begin{array}{l}\text { Approach of } \\
\text { increasing the PRMM }\end{array}$ & $\begin{array}{l}\text { The way of increasing } \\
\text { PRMM }\end{array}$ \\
\hline CMMI-DEV & 6 levels & $\begin{array}{l}\text { PRM is evaluated as the } \\
\text { whole process }\end{array}$ & $\begin{array}{l}\text { Hybrid approach } \\
\text { (Independently + } \\
\text { throughout the system) }\end{array}$ & $\begin{array}{l}\text { Expansion of activities in } \\
\text { the process, integration } \\
\text { into the whole }\end{array}$ \\
\hline OPM3 & 5 levels & $\begin{array}{c}\text { PRM is evaluated as the } \\
\text { whole process }+ \text { Model } \\
\text { distinguishes partial PRM } \\
\text { areas }\end{array}$ & $\begin{array}{l}\text { Independently (but } \\
\text { related best practices } \\
\text { are necessary) }\end{array}$ & Expansion of activities \\
\hline PMMM & 5 levels & $\begin{array}{c}\text { PRM is evaluated as the } \\
\text { whole process }+ \text { Model } \\
\text { distinguishes partial PRM } \\
\text { areas }\end{array}$ & Independently & $\begin{array}{l}\text { Reactive approach, self- } \\
\text { evaluation }\end{array}$ \\
\hline КРMMM & $\begin{array}{l}\text { Not possible to } \\
\text { precisely define }\end{array}$ & $\begin{array}{l}\text { Indirectly within the } \\
\text { maturity of the organization }\end{array}$ & $\begin{array}{l}\text { Indirectly within the } \\
\text { whole }\end{array}$ & $\begin{array}{l}\text { Reactive approach, self- } \\
\text { evaluation }\end{array}$ \\
\hline
\end{tabular}

The first of the analysed characteristics is the possibility to create a specified evaluation scale for project risk management on the basis of the model, as expected property of each maturity model. (Crawford, 2014). In the case of the PMMM and OPM3 models, this is a 5-point scale. In the case of the CMMI model, it is a six-level evaluation, which according to Proença \& Borbinha (2016) may not be entirely appropriate due to excessive granularity. In this respect, for example, the model from Irizar \& Wynn (2018), which works with only 4 stages, is also not entirely suitable. According to Proença \& Borbinha (2016), this scale does not allow organizations and projects to describe a sufficient number of steps of incremental improvement.

In order to be able to further improve the area of risk management, it is important to look at this area from the perspective of partial activities and competencies (second comparative criterion). In the case of the CMMI model, this area is viewed from the perspective of the entire PRM system, while in the OPM3 and PMMM models, specific activities and areas of competence can be deduced. According to the author of this paper, the second of these views is more appropriate if improvement is to be sufficiently targeted and to provide more suitable improvement. (Crawford, 2014, Project Management Institute, Inc., 2013) Despite some disadvantages, the CMMI model could be either used in this case.

The third monitored criterion has an impact on the improvement of PRM itself, which is based on the regularities and interconnectedness of models. For the three suitable models, each of them chooses a slightly different view. In the case of CMMI-DEV, maturity of PRM can be increased to some extent regardless of the remaining aspects of PM. In addition, the OPM3 model, with its interconnectedness of partial best practice, enforces a certain degree of interaction within the entire system while increasing maturity. In contrast, within the PMMM model, it is possible to increase the evaluation completely regardless of other project competencies (or areas) in the organization. Considering that projects do not take place in isolation but in the context of an organization (Cooke-Davies et al., 2009, Project Management Institute, 2013), it will also be necessary to consider the extent to which "advanced PRM" can perform its function properly if other aspects are insufficient. In this case, it seems advantageous to link this area at least to a minimum extent with the context of the whole project management 
system. However, here the author is aware the fact that the model is always used with respect to the needs of the organization (Backlund et al., 2014), and therefore the PMMM model can be considered appropriate.

In the case of the last criterion, the principle of evaluation (and thus increasing) of PRM maturity in the organization is compared. The models can be divided into two categories models that increase the maturity by the expansion of related activities (CMMI-DEV, OPM3) and models working on the principle of self-evaluation of quality of key aspects (PMMM, KPMMM). In this case, it is not possible to evaluate exactly which system is more advantageous. Rather, it is the illustration of principle of how the model is constructed.

In comparison with models specially designed for the field of PRM (section 0), the use of general models for the evaluation of PRM offers an advantage in the form of the possibility to expand (narrow) the range of considered project areas (knowledge areas, competences) according to needs. At the same time, the author of this paper points out that compared to specialized models, it is advantageous to evaluate certain project area (PRM) always in the context of the whole system. Further, partial use of models only for the required areas of project management can partially reduce the general shortcomings associated with evaluation, such as the cost of the entire asset or time. (Staples et al., 2007) On the other hand, such use does not make it possible to eliminate previously identified shortcoming associated with neglection of non-process factors. (Görög, 2016, Nicholas \& Steyn, 2017)

\section{CONCLUSION}

The aim of this work was to analyse PMMMs and evaluate their possibilities as a tool for evaluating the maturity of project risk management, when such an approach should be more effective.

For a closer analysis, the four most frequently used models were selected based on the previous research - CMMI, OPM3, PMMM and KPMMM. The evaluation frameworks of models were described, the levels of maturity and the system of assessment were introduced. At the same time, the role of risk management within the model was described, specifically the way in which this model considers the process and whether it is possible to extrapolate the maturity of this process from the results. Then, the chapter 5 dealt with the comparison of selected models and with the analysis of their suitability. The use of standard maturity models to evaluate the maturity of project risk management has proven to be a possible alternative to the specialized PRMMMs created so far (section 0).

The main contribution of this article is in expanding the base of maturity models to help improve project risk management in organizations. Although there is a further increase in the number of new maturity models specifically developed for certain purpose, this exploratory study uses the reverse process. Namely the use of proven maturity models for assessment and improvement of project sub-areas.

Although project management is a complex discipline, evaluation and adequate project risk management is one of its essential areas. The results of this work will find their application not only in the academic sphere, where PMMMs can also be viewed as models of evaluation of partial project areas. Given that the models are generally based on the principles of selfevaluation, the results of this work will find application in the managerial field. However, further research should be devoted to empirical confirmation based on the use in practice. 


\section{References}

Albrecht, J.C. \& Spang, K. (2014). Project complexity as an influence factor on the balance of costs and benefits in project management maturity modeling. Procedia - Social and Behavioral Sciences, 119, 162-171. doi: 10.1016/j.sbspro.2014.03.020

Backlund, F. Chronéer, D. \& Sundqvist, E. (2014). Project Management Maturity Models-A Critical Review - A case study within Swedish engineering and construction organizations. Procedia - Social and Behavioral Sciences, 119, 837-846. doi:10.1016/j.sbspro.2014.03.094

Bharathi, V., Shastry, U. \& Raj, J. (2012). Bayesian network-based bug-fix effort prediction model. Communications in Computer and Information Science, 290, 233-238. doi:10.1007/978-3-642-30439-2_21

Brooks, N., Butler, M., Dey, P. \& Clark, R. (2014). The use of maturity models in improving project management performance. International Journal of Managing Projects in Business, 7 (2), 231-246. doi: 10.1108/IJMPB-03-2013-0007

Čech, M., Januška, M. \& Faifr, A. (2018). Using Self-Assessment Tool as Part of Risk Management Maturity Model. Proceedings of the 32nd International Business Information Management Association Conference (IBIMA), 3262 - 3285. Retrieved from https://ibima.org/accepted-paper/using-self-assessment-tool-as-part-of-riskmanagement-maturity-model/

Chapman, R.J. (2019). Exploring the value of risk management for projects: improving capability through the deployment of a maturity model. IEEE Engineering Management Review, 47(1), 126-143. doi: 10.1109/EMR.2019.2891494

Cheng, C., Chang, J. \& Kuo, C. (2011). A CMMI appraisal support system based on a fuzzy quantitative benchmarks model. Expert Systems with Applications, 38(4), 4550-4558. doi: 10.1016/j.eswa.2010.09.129

Chrissis, M.B., Konrad, M. \& Shrum,S. (2013). CMMI for Development, Guidelines for Process Integration and Product Improvement. Boston: Addison-Wesley Professional.

Clealand, David I. \& Bidanda, Bopaya. (2015). The Evolution and Maturity of PM. Pensylvania: Project Management Institute, Inc.

Cooke-Davies, T. \& Arzymanow, A. (2003). The maturity of project management in different industries: an investigation into variations between project management models. International Journal of Project Management, 21(6), 471-478. Retrieved from https://www.researchgate.net/publication/222525118_The_maturity_of_project_mana gement_in_different_industries_An_investigation_into_variations_between_project_m anagement_models

Cooke-Davies, T.J., Crawford, L.H. \& Lechler, T.G. (2009). Project management systems: moving project management from an operational to a strategic discipline. Project Management Journal, 40(1), 110-123. doi: 10.1002/pmj.20106

Crawford, J. K. (2006). The Project Management Maturity Model. Information Systems Management, 23(2), 50-58. doi: 10.1201/1078.10580530/46352.23.4.20060901/95113.7

Crawford, J. Kent. (2014). Project Management Maturity Model. Boca Raton: CRC Press.

Crispim, J, Silva, L.H. \& Rego, N. (2018). Project risk management practices: the organizational maturity influence. International Journal of Managing Projects in Business, 12(1), 187-210. doi: 10.1108/IJMPB-10-2017-0122 
de Carvalho, M. \& Rabechini Junior, R. (2014). Impact of risk management on project performance: the importance of soft skills. International Journal of Production Research, 53, 321-340. doi: 10.1080/00207543.2014.919423

Demir, C. \& Kocabas, I. (2010). Project Management Maturity Model (PMMM) in educational organizations. Procedia Social and Behavioral Sciences, 9, 1641-1645. doi: 10.1016/j.sbspro.2010.12.379

Ferreira de Souza, T. \& Gomes, C.F. (2015). Assessment of Maturity in Project Management: A bibliometric Study of Main Models. Procedia Computer Science, 55, 92-101. doi: 0.1016/j.procs.2015.07.012.

Gartner. (2012). The Gartner PPM \& IT Governance Summit 2012. Retrieved from http://docs.media.bitpipe.com/io_10x/io_103373/item_502275/ppm12_summit_broch ure_FINAL.pdf

Gonçalves, T., Oliveira, K. \& Kolski, C. (2018). Identifying HCI approaches to support CMMIDEV for interactive system development. Computer Standards \& Interfaces, 58, 53-86. doi: 10.1016/j.csi.2017.12.003

Flick, U. (2014). An Introduction to Qualitative Research. Thousand Oaks: SAGE

Görög, M. (2013). A Strategic Oriented Implementation of Projects. Pensylvania: Project Management Institute.

Görög, M. (2016). A broader approach to organisational project management maturity assessment. International Journal of Project Management, 34, 1658-1669. doi: 10.1016/j.ijproman.2016.08.011

Grant, K. P., \& Pennypacker, J. S. (2006). Project management maturity: An assessment of project management capabilities among and between selected industries. IEEE Transactions on Engineering Management, 53(1), 59-68. doi: 10.1109/TEM.2005.861802

Iqbal, S. (2013). Organizational maturity: managing programs better. In Levin, G. (Ed.), Program Management: A Life Cycle Approach. Boca Raton: CRC Press/Auerbach.

Hartono, B., Wijaya, DFN \& Arini, HM. (2014). An empirically verified project risk maturity model: evidence from Indonesian construction industry. International Journal of Managing Projects in Business, 7, 263-284. doi: 10.1108/IJMPB-03-2013-0015

Hartono, B., Wijaya, D.F. \& Arini, H. (2019). The impact of project risk management maturity on performance: Complexity as a moderating variable. International Journal of Engineering Business Management, 11. doi: 10.1177/1847979019855504

Hopkinson, M. (2012). The project risk maturity model: measuring and improving risk management capability. Farnham: Gower Publishing, Ltd.

Irfan, M., Hassan, M. \& Hassan, N. (2019). The Effect of Project Management Capabilities on Project Success in Pakistan: An Empirical Investigation. IEEE Access, 7, 39417-39431, doi: 10.1109/ACCESS.2019.2906851

Irizar, J. \& Wynn, M.G. (2018). A new maturity model for project risk management in the automotive industry. International Journal of Risk and Contingency Management, 7 (3), 53-72. doi:10.4018/IJRCM

Keshta, I. (2020). A model for defining project lifecycle phases: Implementation of CMMI level 2 specific practice. Journal of King Saud University-Computer and Information Sciences. doi: 10.1016/j.jksuci.2019.10.013 
Kerzner, H. (2001). Strategic Planning for Project Management using a project management maturity model. New Jersey: John Wiley \& Sons.

Klein, L., Biesenthal, C. \& Dehlin, E. (2015). Improvisation in project management: A praxeology. International Journal of project management, 33(2), 267-277. doi: 10.1016/j.ijproman.2014.01.011

Lune, H. \& Berg, B. (2017). Qualitative Research Methods for the Social Sciences. New York City: Pearson.

Miklosik, A. (2015). Improving project management performance through capability maturity measurement. Paper presented at 3rd Economics \& Finance Conference, Rome, Italy. doi: 10.1016/S2212-5671(15)01264-2

Nicholas, J. \& Steyn, H. (2017). Project Management for Engineering, Business and Technology. Edinburgh: Elsevier.

Marshall, C., \& Rossman, G. B. (2014). Designing qualitative research. New York: Sage Publishing.

Matassa, P. (2006). Grow up already! An OPM3® primer. Paper presented at PMI ${ }^{\circledR}$ Global Congress 2006, Seattle, USA. Retrieved from https://www.pmi.org/learning/library/grow-up-already-opm3-primer-8108

Mishra, A., Das, S., Murray, J. (2015). Risk, Process Maturity, and Project Performance: An Empirical Analysis of US Federal Government Technology Projects. Production and Operations Management, 25(2), 210-232. doi:10.1111/poms.12513

Mullaly, M. (2006). Longitudinal analysis of project management maturity. Project Management Journal, 36(3), 62-73. doi: 10.1177/875697280603700307

Ogonowski, P. \& Madziński, M. (2019). Project Management Maturity in companies operating on Polish logistic market. Scientific Journal of Logistics, 15(2), 223-235. doi: 10.17270/J.LOG.2019.324

Papke-Shields, K. E, Beise, C., \& Quan, J. (2010). Do project managers practice what they preach, and does it matter to project success? International Journal of Project Management, 28, 650-662. doi: 10.1016/j.ijproman.2009.11.002

Pasian, B \& Williams, N. (2014). Extending the concept and modularization of project management maturity with adaptable, human and customer factors. International Journal of Managing Projects in Business, 7(2), 186-214. doi: 10.1108/IJMPB-012014-0006

Pretorius, S., Steyn, H., \& Jordaan, J.C. (2012). Project management maturity and project management success in the engineering and construction industries in Southern Africa. South African Journal of Industrial Engineering, 23 (3), 1-12. doi: 10.7166/23-3-507

Proença, D., \& Borbinha, J. (2016). Maturity models for information systems-A state of the art. Procedia Computer Science, 100, 1042-1049. doi: 10.1016/j.procs.2016.09.279

Project Management Institute. (2004). A Guide to the Project Management Body of Knowledge. Pensylvania: Project Management Institute, Inc.

Project Management Institute. (2013). Organizational project management maturity model (OPM3®). Pensylvania: Project Management Institute, Inc.

Selleri Silva, F., Furtado Soares, F.S., Lima Peres, A., Monteiro de Azevedo, I., Vasconcelos, A.P., Kenji Kamel, F. \& de Lemos Meira, S.R. (2015). Using CMMI together with agile 
software development: A systematic review. Information and Software Technology, 58, 20-43. doi: 10.1016/j.infsof.2014.09.012

Septiana Pane, E. \& Sarno, E. (2015). Capability Maturity Model Integration (CMMI) for Optimizing Object-Oriented Analysis and Design (OOAD). Procedia Computer Science, 72, 40-48. doi: 10.1016/j.procs.2015.12.103

Staples, M., Niazi, M., Jeffery, R., Abrahams, A., Byatt, P. \& Murphy, R. (2007). An exploratory study of why organizations do not adopt CMMI. The Journal of Systems and Software, 80, 883-895. doi: 10.1016/j.jss.2006.09.008

Tahri, H. \& Drissi-Kaitouni, O. (2015). New design for calculating Project Management Maturity (PMM). Procedia - Social and Behavioral Sciences, 181, 171-177. doi: 10.1016/j.sbspro.2015.04.878

Torres, L. (2014). A Contingency View on the Effect of Project Management Maturity on Perceived Performance. Lille: Skema Business School.

von Wangenheim, C., da Silva, D., Buglione, L., Scheidt, R. \& Prikladnicki, R. (2010). Best practice fusion of CMMI-DEV v1.2 (PP, PMC, SAM) and PMBOK 2008. Information and Software Technology, 52, 749-757. doi: 10.1016/j.infsof.2010.03.008

Williams, R.C. (2006). The CMMI RSKM Process Area as a Risk Management Standard. Paper presented at the 16th Annual International Symposium of the International Council on Systems Engineering, Orlando, USA. Retrieved from https://www.demix.org/images/PN05_0750_Williams.Position.pdf

Yazici, H.J., (2009). The role of project management maturity and organizational culture in perceived performance. Project Management Journal, 40(3), 14-33. doi: $10.1002 / \mathrm{pmj} .20121$

\section{Contact information}

\section{Ing. Adam Faifr}

University of West Bohemia, Faculty of Economics

Univerzitni 22, 30614 Plzeň, Czech Republic

E-mail: faifr@kpm.zcu.cz

ORCID: 0000-0002-0740-8012

doi: 10.7441/dokbat.2020.11 